\title{
MODELLING AND SIMULATION OF POTENTIAL FUTURE URBANIZATION SCENARIOS AND ITS EFFECT ON THE MICROCLIMATE OF LOWER SESSION ROAD, BAGUIO CITY
}

\author{
A. Baloloy ${ }^{1 *}$, J. A. Cruz ${ }^{1}$, R. R. Sta. Ana ${ }^{1}$, A. Blanco ${ }^{1,2}$, N. V. Lubrica ${ }^{3}$, C. J. Valdez ${ }^{3}$, J. J. Bernardo ${ }^{3}$ \\ ${ }^{1}$ Training Center for Applied Geodesy and Photogrammetry, University of the Philippines, Diliman, Quezon City \\ 1101, Philippines - alvinbbaloloy@ gmail.com \\ ${ }^{2}$ Department of Geodetic Engineering, University of the Philippines, Diliman, Quezon City, 1101, Philippines \\ ${ }^{3}$ Research and Innovation Office, University of the Cordilleras, Governor Pack Road, Baguio City, 2600, Philippines
}

Commission IV, WG IV/10

KEY WORDS: Urban Heat Islands, Air temperature, ENVI-met, Microclimate modelling, Philippines

\begin{abstract}
:
This paper analyzed both the horizontal and vertical extent of air temperature variations as affected by vegetation leaf area density (LAD) and building area per height threshold. The current microclimate (Scenario 1) and two potential future urbanization scenarios in Lower Session Road, Baguio City were simulated with ENVI-met. The future scenarios include the removal of the Balete trees in the median strip (Scenario 2), and removal of some pine trees and addition of new buildings in the study site (Scenario 3). Remotelysensed data were used in creating the primary model inputs including the initial built-up layer from PlanetScope green-based built-up index (VgNIR-BI), and digital elevation models (DEM) and normalized difference vegetation index (NDVI) maps derived from unmanned aerial system (UAS) for tree canopy mapping. The horizontal variations in air temperature were observed by selecting three subsites with different proximity to the adjusted variables, while vertical analysis was done by comparing the temperature values from the near-ground up to the $20 \mathrm{~m}$ height range. Very minimal temperature change $\left(0^{\circ} \mathrm{C}\right.$ to $\left.-0.01^{\circ} \mathrm{C}\right)$ was observed between the current and simulated scenarios when average temperature of the whole site is obtained. However, temperature variations were better observed with per-subsite analysis as the effects of the adjusted variables are seen to be localized and restricted only to the surrounding thermal condition. Air temperature is highest within 12:00 to 13:00 hours for the three scenarios. In the current scenario, the right region of the study site is cooler in the morning, which gradually became warmer pre-noon up to late afternoon. Removal of Balete trees with Scenario 2 have increased the temperature in the near-ground elevation only, both in Subsites 1 (up to $0.1{ }^{\circ} \mathrm{C}$ ) and 3 (up to $1.6{ }^{\circ} \mathrm{C}$ ), attributed to the loss of surface shadow and reduction in total LAD. In contrast, the removal of pine trees and addition of buildings impacted the air temperature across all subsites and across all atmospheric height ranges. Application of Scenario 3 to Subsite 3 which is close to the adjusted variables, gave the highest near-ground air temperature rise across the study site with a mean value of $1.4{ }^{\circ} \mathrm{C}$ and a maximum value of $1.9{ }^{\circ} \mathrm{C}$. The ENVI-met model of the current scenario generated high accuracy $\left(\mathrm{R}^{2}=0.59\right.$ to 0.99$)$ which implies that the simulation outputs are reliable for this study.
\end{abstract}

\section{INTRODUCTION}

Several studies confirmed that the presence of built-up area can accelerate the effect of Urban Heat Island (UHI), whereas water and green spaces can reduce the UHI intensity. Changes in land use and cover can potentially raise the temperature of the local air and surface temperature with several degrees higher than the temperature values of the surrounding areas. To solve the lack of space to accommodate increasing urban population, green areas are being replaced by urban structures such as asphalt and concrete (Sailor and Lu 2004) which further increases the temperature levels.

It was observed that the rate of urbanization is faster in less developed regions compared to the more developed regions. The level of urbanization is the Philippines is 45.3 percent, suggesting that there is a high proportion of urban population to the total population. Urbanization rate also varies within the country through the development of UHIs and micro-UHIS in its densely populated cities. Baguio City is a tropical mountain city known as the summer capital of the Philippines due to its relatively colder temperature in the summer which attracts tourists locally. It is one of the Philippine cities that experience high rate of urbanization mainly due to land cover changes and

\footnotetext{
* Corresponding author
}

urban sprawl (Baloloy et al., 2019; Estoque and Murayama, 2017). The UHI value have increased from $4.0^{\circ} \mathrm{C}$ in 1987 to $8.2^{\circ} \mathrm{C}$ in 2015 (Estoque and Murayama, 2017). In a recent study, Baloloy et al. (2019) reported that the increase in the built-up extent in Baguio City have significantly intensified the LST during the dry season which was observed in Landsat, PlanetScope and RapidEye data. From an annual average LST of $23.2^{\circ} \mathrm{C}$ in 1990 , the mean LST of Baguio City increased to $27.5^{\circ} \mathrm{C}$ in 2018 , with an increment of $0.11^{\circ} \mathrm{C}$ per year. This trend in the LST will continue if similar rate of built-up expansion will take place particularly within the Central Business District (CBD).

To simulate and map the current and future temperature scenarios, most researchers utilize different methodologies and workflows including both micro and macro modelling. The study and prediction of microclimates have been an interest for decades now (Geiger 1950; Geiger et al, 2003) due to its importance in capturing the local variations in wind, humidity, solar radiation and temperature as influenced by urban morphology parameters (Chatzinikolaou et al., 2018). Several researches have proposed that urban greenery is one of the most cost-effective mitigation strategies against urban heat islands, especially in highly urbanized and rapidly urbanizing cities (Spangenberg, et al., 2008). The temperature reduction due to 
the presence of trees and other vegetation is highly attributed to two factors: shading during daytime and evapotranspiration during night time (Aboelata and Sodoudi, 2019). Variation in the extent and amount of cooling effect provided by vegetation may be due to several factors such as the type and amount of vegetation, geographic location, and urban design. Vegetation characteristics such as leaf area density (LAD) and leaf area index (LAI) are well associated to surface cooling, with high positive correlation results (Gillner et al., 2015; Shinzato and Duarte, 2012).

Contrary to satellite image-derived land surface temperature layers which depict high-density built-up areas as hotspots, microclimate simulation results show that increasing building area or building height does not guarantee that the surface and air temperatures will also increase ( $\mathrm{Li}$ and Donn, 2017). Taller buildings, for example, aid in lowering urban temperature due to its shading effect on the streets level (Perini and Magliocco, 2014). Dursun and Yavas (2018) concluded that variation in different urban configuration such as building heights, building separation, and plot sizes, could possibly result in improved microclimate conditions. Further, it was observed that ground and wall temperature increase with canopy height-to-width ratio (Nazarian and Kleissl, 2015).

The current study aims to stimulate the local current microclimate conditions in Lower Session Road Baguio City, and to determine the impact of (a) removing the Balete vegetation in its median strip, and (b) removing a number of pine trees and adding more built-up structures throughout the study area. These two scenarios will more likely to happen in the future due to the continuous rate of urbanization, and thus modelling the impacts will aid in drawing the necessary mitigation actions. Further, the study will assess the vertical and horizontal extent of the cooling and/or heating effect of vegetation and buildings. Three subsites were selected to better observe the localized effect of each selected scenario, in addition to the mean air temperature variations across the whole study area.

\section{DATA AND METHODS}

\subsection{Study Site}

Baguio City is located within the province of Benguet, northern Luzon Island, Philippines, approximately $250 \mathrm{~km}$ north of Manila. It serves as the regional center of the Cordillera Administrative Region (CAR, Figure 1). Baguio is considered as the country's "Summer Capital" with an annual average temperature of $19.7^{\circ} \mathrm{C}$, generally lower by $8-10^{\circ} \mathrm{C}$ than those of the low land areas. The city has an altitude of 1,417 meters above sea level. The Lower Session Road is the modelling site selected within Baguio CBD. This is a busy road which extends from Magsaysay Avenue until the intersections of Father Carlu Street. The area houses hotels, banks, and other business establishments that are commonly built with concrete materials.

\subsection{ENVI-met Inputs}

A series of field inventory surveys were conducted in 2019 to obtain the vegetation and building information such as wall and roof materials, building height, tree height, crown diameter, and crown circumference (Table 1). Prior to the survey, initial builtup maps were generated using the VgNIR-BI (Estoque and Murayama, 2015) which was utilized in identifying the number and location of buildings to be visited on-site. Each building was assigned with individual shapefile layer and identification number. Other built-up surfaces such as concrete parking lots and small roads were identified using the PlanetScope layer.

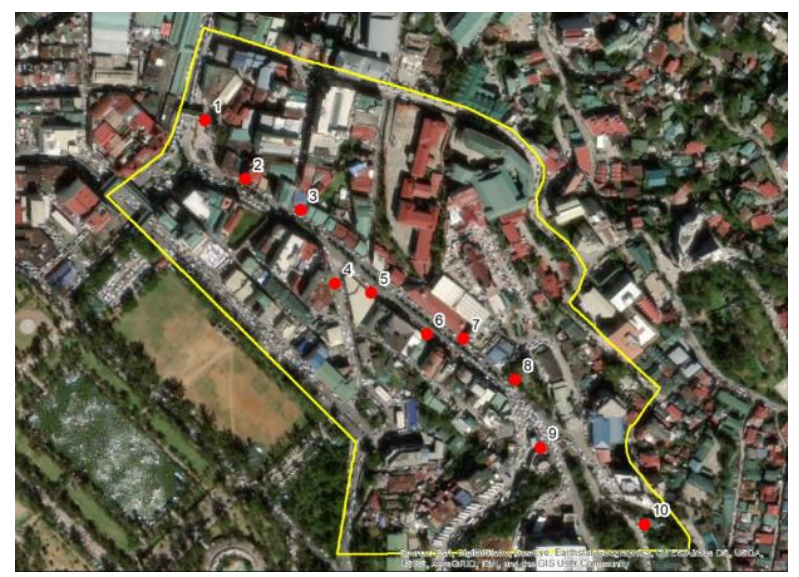

Figure 1. Lower Session Road, Baguio City, bounded by the simulation boundary. The red dots indicate the locations of the 10 receptors with in-situ air temperature measurements.
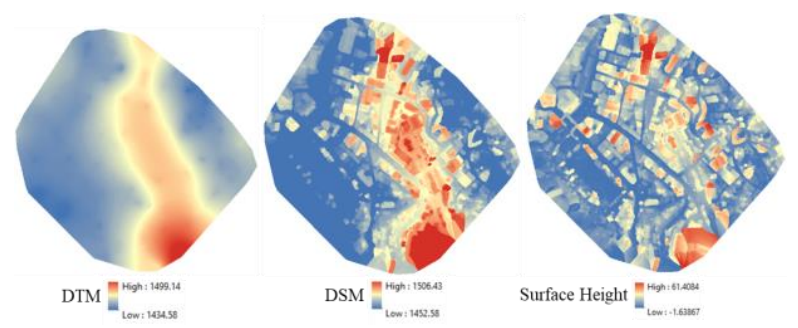

Figure 2. Generated DTM, DSM, and surface heights used in the computation of building and vegetation heights in Session Road.
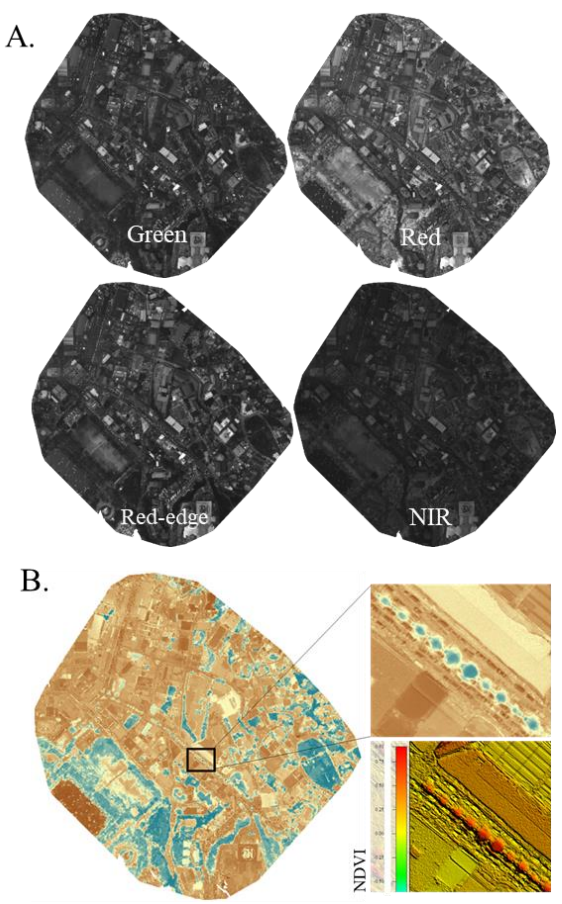

Figure 3. Multispectral bands (green, red, red-edge, and NIR) obtained using Sequoia multispectral camera mounted in Sensefly eBee drone (A). The red and NIR bands were used in generating high resolution NDVI map (B) which aided in isolating individual tree canopies (B, left) in addition to DEMs. 
Drone surveys were conducted to obtain digital elevation models needed in calculating the tree and building heights, in addition to field inventory data (Figure 2). The digital terrain model (DTM) were subtracted from the digital surface model (DSM) to compute for the normalized height of each surface cover.

Individual Balete and pine trees were mapped using the UAVderived NDVI (Figure 3B) using the bands obtained with the Sequoia multispectral camera (Figure 3A). Balete trees and pine trees were then modeled in ENVI-met Albero and were imported as $3 \mathrm{D}$ vegetation in ENVI-met Monde and Spaces. Different height-diameter ratio of pine trees were made, including those with height up to $20 \mathrm{~m}$ and width up to $12 \mathrm{~m}$ (Figure 4A). Vegetation characteristics such as canopy height were carefully modeled as they can alter total LAD. For Balete, smaller tree models were built (Figure 4B). Each of the tree models were assigned with ENVI-met code. The LAD of Balete and pine trees were set to 0.3 and 0.4 per grid, respectively. For root size data, the automatic configuration for each height and width ratio was applied. The foliage shortwave albedo was set to 0.18 while foliage shortwave transmittance was set to 0.30 . The assigned leaf weight is $100 \mathrm{~g} / \mathrm{m}^{2}$ with isoprene capacity of 12 . Grass were considered as simple vegetation layer and was imported as shapefile.

\begin{tabular}{lll}
\hline Input & Parameters Defined & Source \\
\hline $\begin{array}{l}\text { Buildings and } \\
\text { built-up surfaces }\end{array}$ & $\begin{array}{l}\text { Building height, } \\
\text { wall material, roof } \\
\text { material, location }\end{array}$ & $\begin{array}{l}\text { Field inventory, } \\
\text { OpenStreet map, } \\
\text { drone-derived } \\
\text { elevation models }\end{array}$ \\
$\begin{array}{l}\text { Simple Vegetation } \\
\text { (Grass) }\end{array}$ & $\begin{array}{l}\text { Height, plant type, } \\
\text { location }\end{array}$ & Field inventory \\
$\begin{array}{l}\text { Trees (Balete and } \\
\text { Pine trees) }\end{array}$ & $\begin{array}{l}\text { Height, crown } \\
\text { diameter, tree } \\
\text { location }\end{array}$ & $\begin{array}{l}\text { Field inventory, } \\
\text { drone-derived } \\
\text { elevation models }\end{array}$ \\
Road Data & $\begin{array}{l}\text { Surface material, } \\
\text { location }\end{array}$ & $\begin{array}{l}\text { Secondary data, } \\
\text { field inventory }\end{array}$ \\
Receptors & Receptor location & Field inventory \\
\hline
\end{tabular}

Table 1. ENVI-met inputs, information defined and data source. Each inputs were modeled in ENVI-met Monde while 3D vegetation from Albero were added in ENVI-met Spaces.

Wall and roof materials were recorded for each building and was assigned with the respective ENVI-met code such 0100C3 for concrete wall-hollow block and 0100C4 for concrete wall-filled block. Other wall materials listed are wood, glass, and steel. Majority of the building roofs were made of iron (0100IR). The road in lower Session Road is primarily asphalt while most of the open spaces near buildings are paved with concrete materials.

The hourly air temperature and humidity inputs used in the simulation were sourced from Dark Sky, a platform for weather visualization and forecasting (https://darksky.net). The average initial wind direction and speed were also obtained. Meanwhile, the validation data for air temperature were recorded onsite.

\subsection{Simulation Scenarios}

Scenario 1 is the current microclimate scenario in lower Session Road. In Scenario 2, all Balete trees regardless of dimension were removed. Balete tree is one of the unique features in lower Session Road, with around 80 trees planted in the median strip.
In Scenario 3, around ten more buildings were added, taking in consideration the current land areas with bare or grass cover that can be potentially converted into built-up zones. A total of 30 pine trees were removed, with an average of three pine trees removed for each building constructed. Grass areas with newly constructed buildings were also reduced. The total building area of Scenario 1 is 188 ha, which expanded to 198 ha after application of Scenario 3. The removed trees in Scenario 3 is approximately $12 \%$ of the existing 243 pines in the current Scenario.
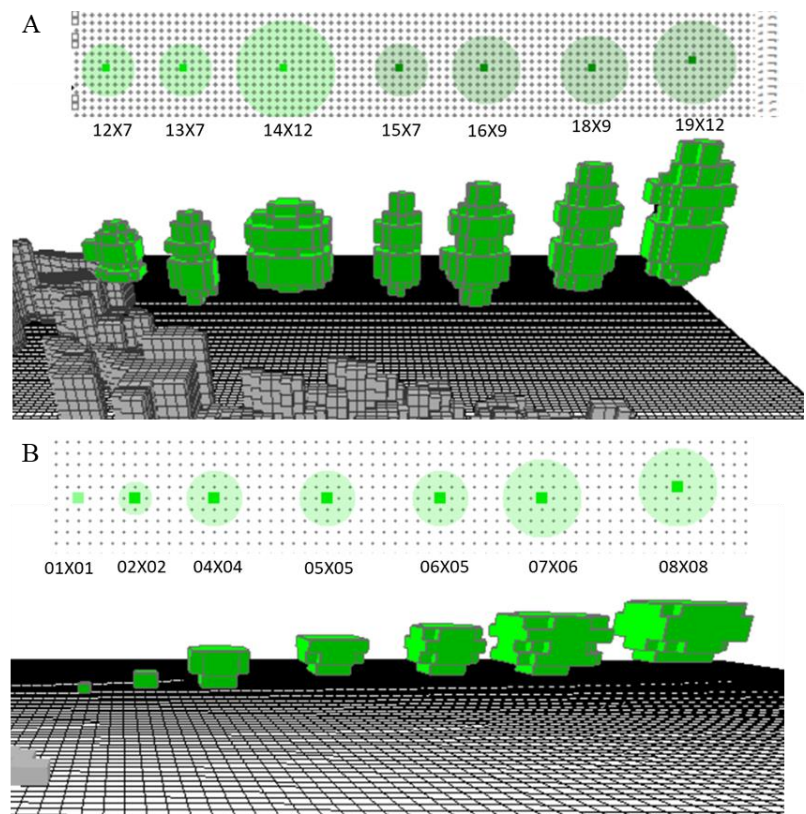

Figure 4. Selected tree models for pine (A) and Balete trees (B) built in ENVI-met Albero based on the field-acquired data on vegetation parameters. The identified Balete and pine trees differ in terms of tree height, canopy height, and crown width. The study developed specific model for each height and width ratio of the trees as this may affect the total LAD per height range.

\subsection{ENVI-met Model}

After identifying the potential future urbanization scenarios, the simulation inputs were imported to the ENVI-met Monde. The scenario models are shown in Figure 5. The visualization is divided into two: the buildings and vegetation layers and the soil and surfaces (Figure 5A). Zooming in the map shows the presence of Balete trees in Scenario 1 (Figure 5B) but not in Scenario 2 (Figure 5C), while additional buildings and less vegetation can be observed in Scenario 3 (Figure 5D).

\subsection{Microclimate Simulation}

The ENVI-met v4.3.4 model is a grid based three-dimensional model for simulating solar radiation, heat and vapor exchange in urban areas. The simulated date is December 22, 2019, from 3:00 to 18:00 hours. The first 3 hours of simulation are within the initialization phase and therefore not included in the analysis.

The simulation settings used are shown in Table 2. The study used simple forcing with hourly inputs for temperature and humidity. The wind speed and wind direction were obtained from secondary data, which are set to $70^{\circ}$ and $2 \mathrm{~m} / \mathrm{s}$, respectively. Common input settings were applied for all three scenarios. The 
total area of the simulated layer is 21.12 ha, with a model dimension of $416 \times 530 \times 40$. In ENVI-met spaces, the base height of the lowest grid box was divided into 5 sub cells. No grid nesting was applied to the simulations.

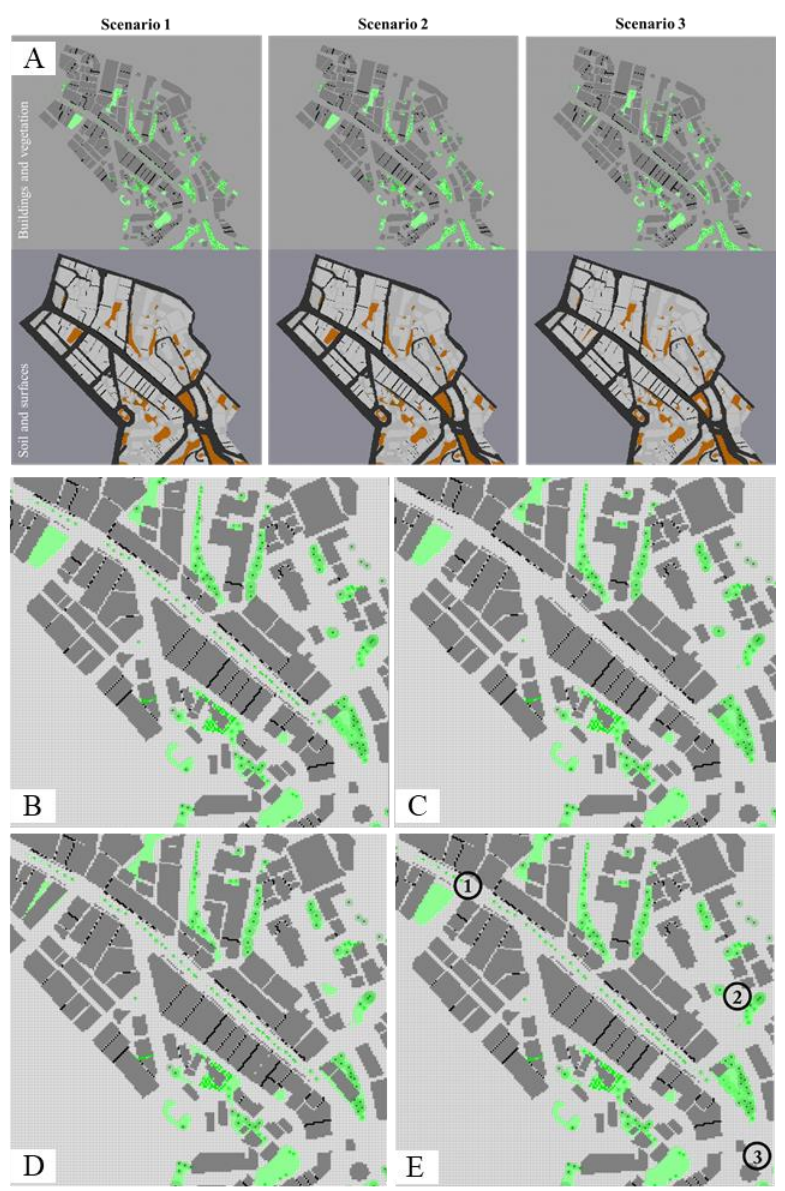

Figure 5. A. ENVI-met simulation models of the three scenarios, showing the building and vegetation layers (top), and soil and surfaces layers. B to D. Zoomed areas showing the difference between the vegetation (green) and building structures (gray) across the scenarios: Scenario 1 or the current scenario (B), Scenario 2 where all Balete trees were removed (C), and Scenario 3 with 10 new buildings added and 30 pine trees removed (D). E. Three smaller subsites were selected within the study site to observe the localized air temperature differences among the three scenarios.

On average, the simulation took 340 hours, including 10 hours for the initialization phase. Moreover, analysis of results and map layout took two weeks using both ENVI-met and ArcGIS software. The simulation output maps and statistics were visualized in ENVI-met Leonardo and ArcGIS software. LAD and building area were extracted from the netCDF files. The mean temperature of the whole study area was obtained by clipping the output raster with the study site boundary shapefile, and masking out buildings from the data. Hourly temperature values were obtained from $6 \mathrm{AM}$ to $6 \mathrm{PM}$. For subsite temperature analysis, local statistics were obtained hourly within different height threshold: $0.2 \mathrm{~m}$ for near-surface height, $2 \mathrm{~m}$ for the thermal comfort elevation range, 5, 10, and 20 meters for vegetation analysis, and up to $30 \mathrm{~m}$ to observe the effect of new buildings. Statistics of hourly potential air temperature across elevations were compared between the simulation scenarios.

\begin{tabular}{ll}
\hline Parameters & Values \\
\hline Start of simulation & $3: 00$ \\
Simulation hours & 15 \\
$\begin{array}{l}\text { Wind speed at } 10 \mathrm{~m} \text { above ground } \\
\text { level }\end{array}$ & $2 \mathrm{~m} / \mathrm{s}$ \\
Wind direction & $70^{\circ}$ \\
Initial temperature range $\left({ }^{\circ} \mathrm{C}\right)$ & 17 to 25 \\
Initial humidity range $(\mathrm{g} \mathrm{Water} / \mathrm{kg}$ air $)$ & 0.6 to 0.97 \\
Simulation level & Intermediate \\
Boundary condition & Simple forcing \\
Roughness length & 0.02 \\
\hline
\end{tabular}

Table 2. Input settings applied to the ENVI-met simulation of current and potential scenarios. The model used intermediatelevel simulation with simple forcing from 24 hours data.

\subsection{Subsites Analysis}

Three subsites were selected within the Lower Session Road to highlight unique observations in each scenario outputs. Subsite 1 is near receptor 3 in the northern part of the study area. It is located near the Balete trees in the median strip, and near an added building (20m height) and reduced grass area (Figure 5E). In this site, air temperature is expected to be affected both by Scenario 2 and Scenario 3 due to its proximity to the added and removed inputs. Meanwhile, subsite 2 is near Receptor 9 in the southern part of lower Session Road. It is far from Balete, removed pine trees, and with the new buildings added. The area also has the least building density and has the widest exposed road area. This site will be utilized in observing the effect of Scenarios 2 and 3 to areas that are far from adjusted input variables. Lastly, subsite 3 is located almost near the middle portion, in proximity to the added buildings and removed vegetation, making it an ideal site to observe the effect of Scenario 3 .

\subsection{On-site Measurement of Air Temperature}

To evaluate the accuracy of the ENVI-met simulation, the relationship between hourly in-situ air temperature and simulated air temperature data at the height of 1.8 meters was analyzed. On-site air temperature measurement was conducted from December 11 to 16, 2019 using ten $\mathrm{HOBO}{ }^{\circledR}$ MX100 Data Loggers with an accuracy of $\pm 0.5^{\circ} \mathrm{C}$ for a temperature range of $-5^{\circ}$ to $50^{\circ} \mathrm{C}$. The sensors were deployed evenly along Lower Session Road (Figure 1).

\section{RESULTS AND DISCUSSION}

\subsection{LAD Profile}

The total LAD was computed for each height range (Figure 6). The highest total LAD was recorded at $0.2 \mathrm{~m}$ height, dominated by grass $\left(1194 \mathrm{~m}^{2} / \mathrm{m}^{3}\right)$. Lowest total LAD was recorded at $2 \mathrm{~m}$ with both small pines and small Balete trees. After running Scenario 2, the LAD decreased within the $0.2 \mathrm{~m}$ to $5 \mathrm{~m}$ height only, as the tree heights of the Balete trees only reaches this 
level. The difference between the LAD in Scenario 2 and the current scenario is $28.9 \mathrm{~m}^{2} / \mathrm{m}^{3}, 10 \mathrm{~m}^{2} / \mathrm{m}^{3}$, and $4 \mathrm{~m}^{2} / \mathrm{m}^{3}$ for heights $5 \mathrm{~m}, 2 \mathrm{~m}$, and $0.2 \mathrm{~m}$, respectively. Majority of the Balete are within the $5 \mathrm{~m}$ height, resulting to the largest decrease in this level. Removing pine trees and grass to give way to new buildings in Scenario 3 significantly causes larger difference in vegetation $L A D$, and this was observed all throughout the height ranges. Most of the pine trees have $10 \mathrm{~m}$ to $12 \mathrm{~m}$ tree height, resulting to the highest decrease in $\mathrm{LAD}$ (minus $154 \mathrm{~m}^{2} / \mathrm{m}^{3}$ ) at this level. It was followed by the difference in LAD at $0.2 \mathrm{~m}$ height (minus $104 \mathrm{~m}^{2} / \mathrm{m}^{3}$ ) which is mainly attributed to the removed grass. In terms of resulting leaf temperature, the lower the vegetation height, the higher maximum leaf temperature values were recorded. Vegetation height and leaf temperature have strong negative correlation, with $r=0.97$ at $\alpha=0.001$.

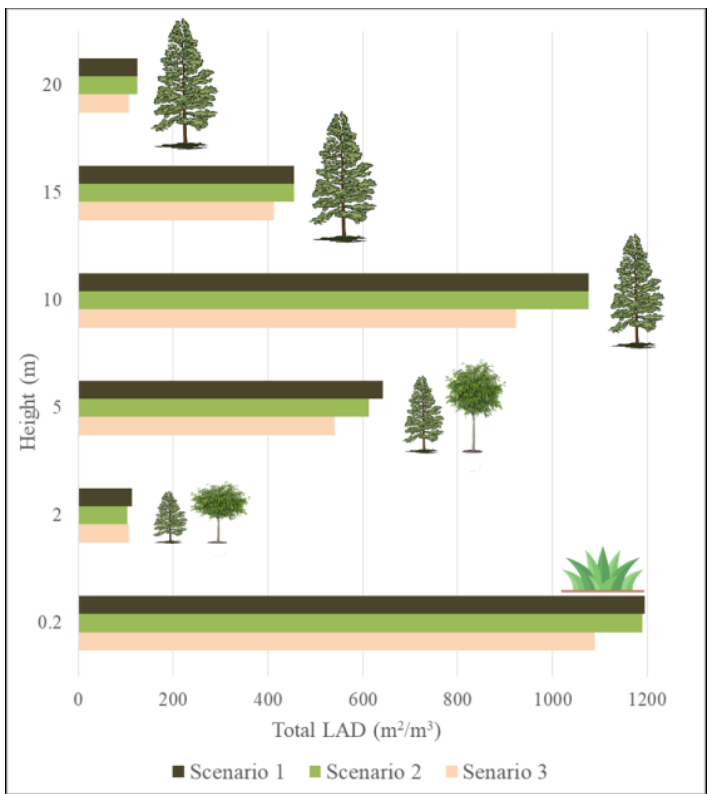

Figure 6. Variations in the total LAD for each simulation scenario in Lower Session Road, Baguio City. Each height range is dominated by either grass, Balete trees, Pines, or a combination of two vegetation types.

\subsection{Building Profile}

This paper utilized 'total building area' per height range rather than building density, since the later only account for the number of buildings per unit area. The differences in building area and form may affect wind flow, wind direction, and the surrounding air temperature (Dursun and Yavas, 2018). In the current scenario, the highest total building area was computed within the $0.2 \mathrm{~m}$ and $2 \mathrm{~m}$ elevation, with both 8.46 ha. Application of Scenario 3 have increased the total building area to $8.73 \mathrm{~m}$ for heights $0.2 \mathrm{~m}, 2 \mathrm{~m}$ and $5 \mathrm{~m}$. The largest area increases were recorded for heights $5 \mathrm{~m}$ to 15 , with 0.41 ha to 0.42 ha added.

\subsection{Mean Temperature per Scenario}

In all scenarios, the air temperature is highest within 12:00 to 13:00 hours. The right region of the study site is cooler in the morning, which gradually became warmer pre-noon up to late afternoon (Figure 7). The right portion have less building density with more scattered vegetation. In the current scenario (Figure 7), the maximum air temperature was simulated at 14:00 with $24.2{ }^{\circ} \mathrm{C}$, similar to the result from Scenario 2, and close to the result $\left(24.2^{\circ} \mathrm{C}\right)$ from Scenario 3. The air temperature throughout the simulated hours is shown in Figure 8 where similar trend across all scenarios was observed.

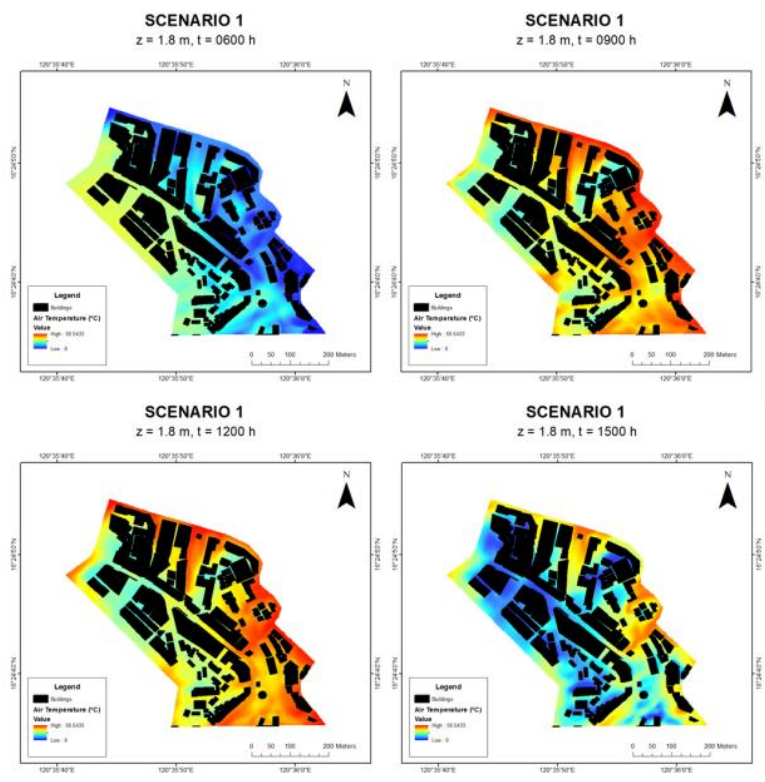

Figure 7. Simulated air temperature at $1.8 \mathrm{~m}$ for the current scenario (Scenario 1) during 6:00, 9:00, 12:00 and 15:00 hours in lower Session Road, Baguio City.

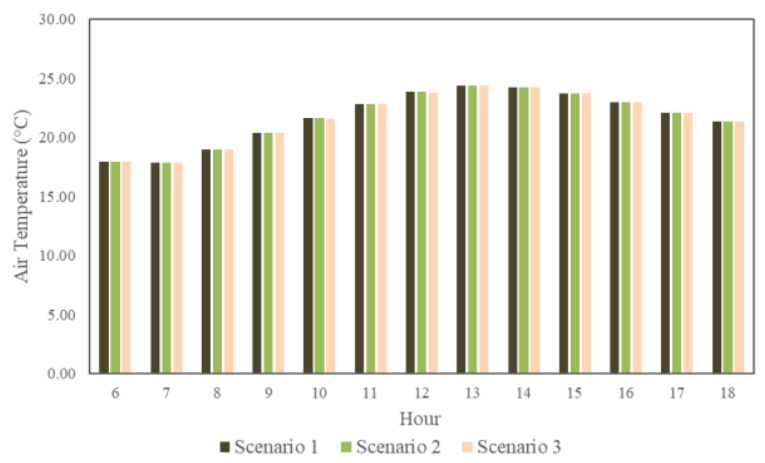

Figure 8 . Hourly trend of simulated air temperature at $1.8 \mathrm{~m}$ for the three scenarios in Lower Session Road, Baguio City. Similar trend was observed with peak air temperature at 13:00.

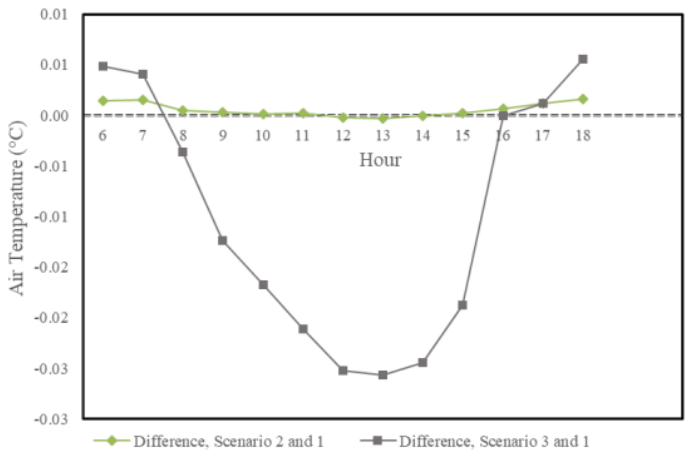

Figure 9. Difference in the hourly air temperature between scenarios 3 and 1 , and between scenarios 2 and 1 . Very minimal difference were observed in all the scenarios, with Scenario 3 leading to a decrease in air temperature from 8:00 to 15:00. 
Since the difference is too small as seen in the previous graph, Figure 9 highlighted the differences between scenarios 2 and 1 (green line) and between scenarios 3 and 1 (gray line). Almost no difference was observed between the mean temperature of Scenarios 1 and 2. A minimal decrease up to minus $0.003{ }^{\circ} \mathrm{C}$ was observed between Scenario 1 and 3, although the value is almost negligible. This result shows that the effect of changing scenarios may not be well observed if the mean value for the whole study site will be computed. There are areas far from either added buildings or remove vegetation, and these may just counterbalance any increase or decrease in selected areas. Thus, local mean temperature observation is required to capture the microclimate condition changes relative to the current scenario.

\subsection{Subsite Temperature Analysis}

More local and site-specific observations were observed through analysis of air temperature differences in three selected subsites with different characteristics and proximity to the adjusted variables through Scenarios 2 and 3 (see Figure 10). The hourly potential temperature was collected in the 0 to $20 \mathrm{~m}$ height range from each subsite with fixed pixel size ( $2 \mathrm{~m}$ resolution) and location. Minimal subsite extent was adopted to allow measurement of air temperature from open space without direct contact to the nearby vegetation and building structures.

\subsubsection{Air Temperature Variations in Subsite 1}

In subsite 1 , Scenario 2 resulted to a slightly higher temperature rise up to $0.1^{\circ} \mathrm{C}$ which was mainly observed within the $0.2 \mathrm{~m}$ height only (Figure 10). This is attributed to the absence of surface shadow from the removed Balete trees especially at the near-surface elevation. Meanwhile, in the Balete-canopy height level $(5 \mathrm{~m})$ with the largest LAD change, the temperature is minimally cooler. In contrast, Scenario 3 led to an increase in air temperature not only in the near-surface height but up to the $10 \mathrm{~m}$ elevation. Higher near-surface air temperatures were recorded, with a mean increase of $0.4{ }^{\circ} \mathrm{C}$ and a maximum increase up to $0.6{ }^{\circ} \mathrm{C}$. Warmer near-surface air temperatures were observed from 10:00 to 14:00 in Scenario 2 while it further extends until 17:00 for Scenario 3. The pine trees and grass near Subsite 1 recorded greater loss in LAD than the Balete trees near the road.

\subsubsection{Air Temperature Variations in Subsite 2}

Due to its location, removing Balete trees with Scenario 2 have not cause significant change in the air temperature in Subsite 2 due to its distance from the said vegetation (Figure 10). It however caused a very minimal mean increase of $0.01{ }^{\circ} \mathrm{C}$ in the near-ground air temperature from 13:00 to 17:00 (Figure 10). Application of Scenario 3 to Subsite 2 have lessen the air temperature within $0.2 \mathrm{~m}$ to $20 \mathrm{~m}$ height range from 9:00 to 13:00. Meanwhile, the said scenario resulted to warmer temperature in the early morning (6:00 to 7:00) and in the afternoon (14:00 to 17:00) with a mean increase of $0.3{ }^{\circ} \mathrm{C}$ and a maximum increase up to $0.5^{\circ} \mathrm{C}$. Warmer temperature in the late afternoon could be a result of lower evapotranspiration efficiency due to less trees nearby. Regardless of positive or negative temperature change, the observation always extends up to the $20 \mathrm{~m}$ height.

\subsubsection{Air Temperature Variations in Subsite 3}

Interestingly, removing the Balete trees with Scenario 2 have increased the surface air temperature on the right side of the study area (Figure 10). This rise in temperature level was only observed at the near-ground elevation, with a mean increase of
$1.1{ }^{\circ} \mathrm{C}$ and a maximum increase of $1.6^{\circ} \mathrm{C}$. Similar with Subsites 2 and 3 , removing pine trees and adding building (Scenario 3 ) in Subsite 3 have affected the temperature level up to the $10 \mathrm{~m}$ and $20 \mathrm{~m}$ heights. Scenario 3 resulted to a consistent temperature rise from 8:00 to 15:00 across all height levels (Figure 10), with higher level of increase observed in $2 \mathrm{~m}$ and 0.2 elevation. Among all scenarios and subsites, Subsite 3 and Scenario 3 gave the highest air temperature rise within the near-ground elevation, with a mean value of $1.4{ }^{\circ} \mathrm{C}$ and a maximum value of $1.9^{\circ} \mathrm{C}$. The temperature started to cool down after 15:00.

\subsection{Temperature as affected by Vegetation and Buildings}

The removal of Balete trees have impacted Subsites 1 and 3, with higher air temperature up to $0.1{ }^{\circ} \mathrm{C}$ and $1.6^{\circ} \mathrm{C}$, respectively. In Subsite 1, the main driver of the change is the absence of tree shadow on the ground. The minimal level of temperature rise can be attributed to the low total LAD of Balete trees in the current scenario. At $0.2 \mathrm{~m}$ height for example, only $104 \mathrm{~m}^{2} / \mathrm{m}^{3}$ were lost. Further, Balete trees at the northern region are mostly shorter, younger, and with larger planting gaps.

The $1.6{ }^{\circ} \mathrm{C}$ maximum increase in Subsite 3 after removing the Balete trees is close to temperature reduction when trees are added instead, as reported by previous studies. The cooling effect of trees varies from $1{ }^{\circ} \mathrm{C}$ to $0.5{ }^{\circ} \mathrm{C}$ (Kong et al., 2016; Maiyoma et al., 2009). Subsite 3 is just approximately $80 \mathrm{~m}$ away from the Balete trees. Although Subsite 1 is closer to the median strip, the Balete trees located in the opposite region near Subsite 3 are denser, taller, and with wider canopy width. In addition, two of the larger Balete tree models are located in a street perpendicular to Subsite 3. The effect of removing the Balete trees to the near-ground air temperature of nearby sites may be caused by localized air convection and change in wind turbulence (Kong et al., 2016), although the actual mechanism was not completely observed in the simulation.

Meanwhile, the effect of removing pine trees extended up to $20 \mathrm{~m}$ height range due to taller tree and canopy heights. A previous research reported that vegetation can provide vertical cooling effect up to the mean building height (Kong et al., 2016). In the current study, the temperature rise induced by removing vegetation also extended up to the mean building height which is $17 \mathrm{~m}$. Vegetation that occur within green parks, like the pine trees in this study, are reported to have more cooling effects than roadside vegetation (Petralli et al., 2006). It is important to note that Scenario 3 considered both vegetation and buildings, thus simulation result must be attributed to the joint effect of these variables. The addition of new tall buildings in Lower Session Road have led to vertical air temperature increase, similar to the studies reviewed by of $\mathrm{Li}$ and Donn (2017) which they have attributed mainly to the change in airflow rate. As seen in Figure 11 , the increase in building area resulted to air temperature rise across all height range, up to $30 \mathrm{~m}$. The overall correlation between air temperature and building area increase is weak $\left(\mathrm{R}^{2}=0.17\right)$ which is mainly affected by the trend variations per height threshold. Below the mean building height $(0.2 \mathrm{~m}$ to $10 \mathrm{~m})$, the level of temperature rise decreases as the change in building area increases $\left(\mathrm{R}^{2}=0.96\right)$, but this is also well correlated with increasing elevation $\left(\mathrm{R}^{2}=0.99\right)$ (Figure 11). The temperature increase within $0.2 \mathrm{~m}$ to $10 \mathrm{~m}$ heights is high $\left(+0.5^{\circ} \mathrm{C}\right.$ to $\left.1.2^{\circ} \mathrm{C}\right)$ as this range is both affected by buildings and pine trees. Adding buildings potentially contributed to near ground temperature due to the thermal behavior of the wall and roof materials. The heavy use of block type materials such as concrete in the study area is considered the main cause of direct heat release. Within the 


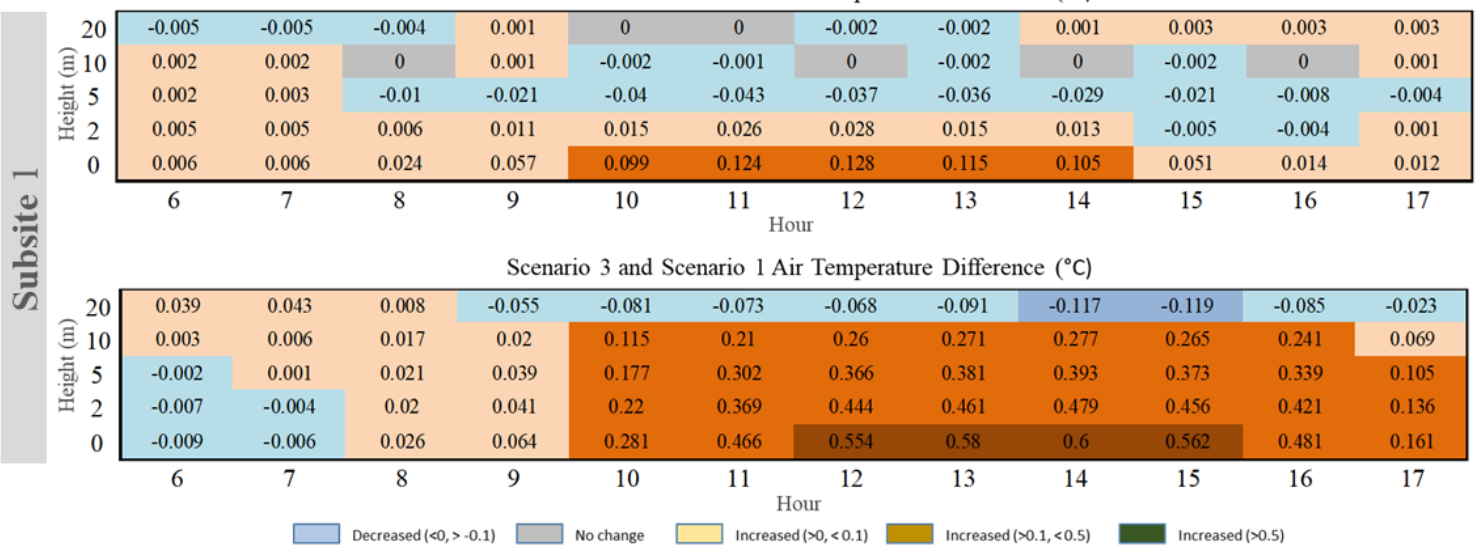

\begin{tabular}{|c|c|c|c|c|c|c|c|c|c|c|c|c|c|}
\hline \multirow{12}{*}{ 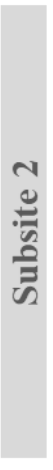 } & 20 & 0.002 & 0.002 & -0.002 & -0.002 & 0 & 0.001 & 0.001 & 0.001 & 0.002 & 0.001 & -0.001 & -0.002 \\
\hline & $\widehat{\Xi} 10$ & -0.007 & -0.007 & 0.006 & 0.013 & 0.019 & 0.019 & 0.017 & 0.015 & 0.015 & 0.014 & 0.012 & 0.008 \\
\hline & 할 5 & -0.009 & -0.009 & 0.003 & -0.013 & -0.031 & -0.025 & 0 & 0.028 & 0.041 & 0.033 & 0.019 & 0.008 \\
\hline & 可 2 & 0.005 & 0.005 & -0.005 & 0.002 & 0.008 & 0 & -0.014 & -0.024 & -0.015 & -0.009 & -0.001 & -0.004 \\
\hline & 0 & 0.006 & 0.007 & -0.006 & 0.012 & -0.002 & -0.017 & -0.015 & 0.006 & 0.016 & 0.014 & 0.025 & 0.002 \\
\hline & & 6 & 7 & 8 & 9 & 10 & 11 & 12 & 13 & 14 & 15 & 16 & 17 \\
\hline & & & & & Scer & 3 and & enario 1 & Temper & e Differ & $\left({ }^{\circ} \mathrm{C}\right)$ & & & \\
\hline & 20 & 0.087 & 0.077 & 0.048 & -0.07 & -0.156 & -0.307 & -0.369 & -0.333 & -0.142 & 0.032 & 0.202 & 0.176 \\
\hline & छ 10 & 0.117 & 0.107 & 0.06 & -0.033 & -0.053 & -0.175 & -0.224 & -0.142 & 0.108 & 0.3 & 0.435 & 0.236 \\
\hline & 흠 5 & 0.133 & 0.124 & 0.067 & -0.045 & -0.075 & -0.186 & -0.219 & -0.111 & 0.159 & 0.359 & 0.476 & 0.238 \\
\hline & 亲 2 & 0.132 & 0.124 & 0.08 & -0.041 & -0.072 & -0.17 & -0.193 & -0.047 & 0.256 & 0.455 & 0.538 & 0.251 \\
\hline & 0 & 0.135 & 0.128 & 0.081 & -0.052 & -0.118 & -0.222 & -0.244 & -0.06 & 0.259 & 0.459 & 0.533 & 0.24 \\
\hline & & 6 & 7 & 8 & 9 & 10 & 11 & 12 & 13 & 14 & 15 & 16 & 17 \\
\hline
\end{tabular}

Scenario 2 and Scenario 1 Air Temperature Difference $\left({ }^{\circ} \mathrm{C}\right)$

\begin{tabular}{|c|c|c|c|c|c|c|c|c|c|c|c|c|c|}
\hline \multirow{12}{*}{ ڤ } & 20 & -0.001 & 0.001 & 0.001 & 0 & -0.006 & -0.004 & -0.006 & -0.012 & -0.026 & -0.037 & -0.042 & -0.03 \\
\hline & 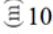 & 0.001 & 0.001 & 0 & -0.001 & -0.002 & -0.001 & -0.001 & -0.001 & -0.001 & 0 & 0 & 0 \\
\hline & 금 5 & -0.003 & -0.002 & 0.008 & 0.015 & 0.013 & 0.008 & 0.002 & -0.003 & -0.01 & -0.014 & -0.003 & -0.001 \\
\hline & 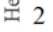 & 0.001 & 0 & -0.034 & -0.056 & -0.046 & -0.051 & -0.05 & -0.042 & -0.022 & -0.003 & -0.01 & -0.005 \\
\hline & 0 & -0.202 & -0.223 & 0.278 & 0.652 & 1.019 & 1.264 & 1.426 & 1.517 & 1.623 & 1.512 & 1.039 & 0.568 \\
\hline & & 6 & 7 & 8 & 9 & 10 & & 12 & 13 & 14 & 15 & 16 & 17 \\
\hline & & & & & Scer & 3 and & ario 1 & Temper & Differ & $\left({ }^{\circ} \mathrm{C}\right)$ & & & \\
\hline & 20 & -0.013 & -0.021 & 0.008 & 0.024 & 0.044 & 0.033 & 0.045 & 0.053 & 0.048 & 0.03 & -0.65 & -0.652 \\
\hline & 当 10 & -0.024 & -0.014 & 0.001 & 0.019 & 0.072 & 0.067 & 0.077 & 0.073 & 0.077 & 0.062 & -0.867 & -0.759 \\
\hline & 믈 5 & -0.016 & -0.021 & 0.015 & 0.004 & 0.091 & 0.099 & 0.139 & 0.119 & 0.118 & 0.062 & -0.967 & -0.808 \\
\hline & ज壮 2 & -0.032 & -0.029 & 0.018 & 0.136 & 0.324 & 0.299 & 0.377 & 0.284 & 0.245 & 0.012 & -1.045 & -0.862 \\
\hline & 0 & -0.239 & -0.246 & 0.261 & 0.764 & 1.296 & 1.616 & 1.887 & 1.855 & 1.935 & 1.427 & -0.051 & -0.326 \\
\hline & & 6 & 7 & 8 & 9 & 10 & 11 & 12 & 13 & 14 & 15 & 16 & 17 \\
\hline
\end{tabular}

Figure 10. Air temperature differences between Scenarios 3 and 1, and Scenarios 2 and 1 in each of the subsites selected within lower Session Road, Baguio City. Temperatures highlighted in gray have not changed, blue have decreased, while orange, dark orange, and brown have increased. Scenario 3 consistently increased surface temperature across all atmospheric elevations especially for 1 and 3.

mean building height $(15 \mathrm{~m})$, very minimal temperature rise was observed $\left(+0.08^{\circ} \mathrm{C}\right)$, extending up to $30 \mathrm{~m}$. In elevations beyond this level $(15 \mathrm{~m}$ to $30 \mathrm{~m})$, very small pine tree LAD was removed and thus, the increase in temperature can be attributed mainly to the added buildings. Its sole effect has been very minimal from $0.02^{\circ} \mathrm{C}$ to $0.2^{\circ} \mathrm{C}$. Lower temperature increase within these elevations could be driven by other factors such as airflow and wind direction. In most subsites and scenarios, the removal of vegetation and addition of new buildings in the study site have not increased the potential air temperature during early morning.

\subsection{Accuracy Assessment}

Results of the validation show strong agreement between the field-acquired air temperature measurements and the simulated air temperature values, as evidenced by its overall high coefficient of determination values $\left(\mathrm{R}^{2}=0.59-0.99\right)$ and low mean absolute percentage error (MAPE $=3.83 \%-15.48 \%)$. Deviations between the two datasets could be possibly due to either the external effects that could have influenced the measured air temperature on-site, or the inherent limitations of 
the created model and the ENVI-met software. Sensor 6, for example, which obtained the lowest correlation $\left(\mathrm{R}^{2}=0.59\right.$, was installed on an unshaded area. The highest correlation was observed in receptor $10\left(\mathrm{R}^{2}=0.99\right)$ and receptor $2\left(\mathrm{R}^{2}=0.97\right)$.

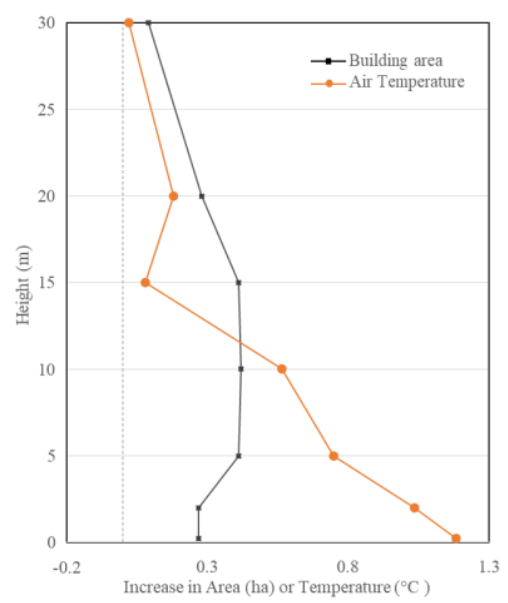

Figure 11. Increase in total building area and the corresponding increase in air temperature per atmospheric height in Subsite 3. Temperature rise within $0.2 \mathrm{~m}$ to $10 \mathrm{~m}$ were affected by both vegetation and buildings, while the temperature rise within $15 \mathrm{~m}$ and above was attributed to the effect of newly added buildings.

\section{CONCLUSION}

Three scenarios were simulated including the current scenario and two potential future urbanization scenarios: removal of Balete trees (Scenario 2) and removal of pine trees to add more buildings (Scenario3). Results show that the effects of the future scenarios are localized and are induced by the changes in the surrounding urban features. The effect of removing Balete has affected those areas close to the median strip, while the addition of buildings and removal of Pines exhibited more significant effect to areas near the altered variables. Both vegetation LAD and building area have explained changes in air temperature. Removal of vegetation with low LAD in lower heights increased the air temperature in the near-ground elevation only, while LAD of taller trees can alter temperature up to the mean building height. The new buildings have induced air temperature in the lower elevations due to released heat, in addition to the shadow coverage lost by removing pine trees. Moreover, the temperature effect of increasing building area beyond the mean building height is minimal. The results of the study suggest that although the effects are localized, vegetation loss and intensive building construction can directly worsen the impacts of UHI in lower Session Road, Baguio City.

\section{ACKNOWLEDGEMENTS}

The authors would like to acknowledge the Philippine Council for Industry, Energy, and Emerging Technology Research and Development (PCIEERD) of the Department of Science and Technology (DOST), Republic of the Philippines for funding and monitoring, Project No. 4028, a nationwide research entitled Geospatial Assessment and Modelling of Urban Heat Islands in Philippine Cities (GUHeat).

\section{REFERENCES}

Baloloy, A., Sta. Ana, R. R., Cruz, J. A., Blanco, A. C., Lubrica, N. V., Valdez, C. J., Cajucom, E. P., 2019. Spatiotemporal multi- satellite biophysical data analysis of the effect of urbanization on land surface and air temperature in Baguio city, Philippines. Int. Arch. Photogramm. Remote Sens. Spatial Inf. Sci. pp47-54.

Chatzinikolaou, E., Chalkias, C., Dimopoulou, E., 2018. Urban microclimate improvement using ENVI-met climate model. Int. Arch. Photogramm. Remote Sens. Spatial Inf. Sci. pp69-76.

Crank, P.J., Sailor, D.J., Ban-Weiss, G., Taleghani, M., 2018. Evaluating the ENVI-met microscale model for suitability in analysis of targeted urban heat mitigation strategies. Urban Climate. 26, pp188-197.

Dursun, D., Yavas, M., 2018. Microclimate analysis of different urban forms in cold climates and the effect of thermal comfort. Int. Arch. Photogramm. Remote Sens. Spatial Inf. Sci. 155-160.

Estoque, R.C., Murayama, Y., 2017. Monitoring surface urban heat island formation in a tropical mountain city using Landsat data (1987-2015). ISPRS J Photogramm. pp18-29.

Geiger, R., 1950. The Climate near the Ground. Harvard University Press, Cambridge, MA.

Geiger, R., Aron, R.H., Todhunter, P., 2003. The Climate near the Ground. Rowman and Littlefield, New York.

Gillner, S.; Vogt, J., Tharang, A., Dettmann, S., Roloff, A., 2015. Role of street trees in mitigating effects of heat and drought at highly sealed urban sites. Landsc. Urban Plan. 143, pp33-42.

Kong, F., Sun, C., Liu, F., Yin, H., Jiang, F., Pu, Y., Cavan, G., Skelhorn, C., Middel, A., Dronova, I., 2016. Energy saving potential of fragmented green spaces due to their temperature regulating ecosystem services in the summer. Appl. Energy. 183.

Li, J., Donn, M., 2017. The influence of building height variability on natural ventilation and neighbour buildings in dense urban areas. Proceedings of the $15^{\text {th }}$ IBPSA Conference.

Maiyoma, M., Tanaka, T., Iwasaki, M., 2009. The mitigation of UHI intensity by the improvement of land use plan in the urban central area application to Osaka city, Japan, J. Heat Isl. Inst. Int.

Nazarian, N., Kleissl, J., 2015. CFD simulation of an idealized urban environment: Thermal effects of geometrical characteristics and surface materials. Urban Climate. 12, pp141159 .

Perini, K., Magliocco, A. Effects of vegetation, urban density, building height, \& atmospheric conditions on local temperatures and thermal comfort. Urban for Urban Gree.495-506.

Petralli, M., Andras,P., Morabito, M. 2006. Role of green areas in urban heat island mitigation: a case study in Florence (Italy). Sezione Scientifica. pp51-58.

Sailor, D., Lu, L., 2004. A Top-Down methodology for developing diurnal and seasonal anthropogenic heating profiles for urban areas. Atmos. Environ. 38, pp2737-2748.

Spangenberg, J., Shinzato, J., Johansson, E., Duarte, D., 2008. Simulation of the influence of vegetation on microclimate and thermal comfort in the city of São Paulo. Piracicaba. 3, pp1-19. 